\title{
CORRESPONDENCE
}

\section{Science and Development}

SIR,-I wish that your discussion of the relevance of science in developing countries (Nature, 232, 73; 1971) could have started some 25 years ago when, after centuries of foreign rule, most of the countries under the old British Empire were beginning to emerge as free nations. It could probably then have saved some of the new governments of those countries from taking decisions which have led to serious economic and social problems. The crying need of millions of people in these countries is for food and shelter and if science and technology has any relevance to humanity then it should be the foremost aim to provide these basic necessities as soon as possible. Development of agriculture and the related industry must therefore be the first task. In order to develop agriculture the research must be oriented to develop better strains of wheat, rice, etc., on one hand and "intermediate" tools of agriculture on the other hand. (What I mean by "intermediate" tools is the sort of tools which are in between the primitive plough drawn by the horse or bullock and the complex tractor.) The intermediate tools would have the advantage that they could be more efficient than the primitive tools used at present and be mechanically simple to be looked after by the simple farmer himself.

Communication to the men in the villages of these countries (and about $80 \%$ of the population in a country like India lives in villages) is another equally, if not the most, important aspect to which very little attention has been paid with the result that whatever developments were made in these fields remained confined to reports in the files of government officials.

Without the communication of these new developments to the farmers in the villages, no real progress on the farms can be achieved since it is the farmers in the villages and not the officials who work on the farm. I believe that it is here that the medium of television could provide the means to communicate to the farmer, in his own language, the new developments in tilling the soil, sowing, fertilizers, maintenance of his tools, etc., since any written material, such as books, is no good to him because he cannot read. Even illiteracy could be effectively tackled by the programmes on the television specially designed for this purpose. Italy is known to have achieved, during the last decade, a great success in its agriculture and literacy programme by use of television. I am sure the same can be done in the case of developing nations. Here is a place for the advanced technology in the economics and social advancement of slowly advancing countries.

Education of the illiterate masses through television, I am sure, will make a great impact on the quality of life to millions of people and bring about an awareness of the world around them. As such, at present they are in complete darkness about the better way of life existing a few miles away in their own land, not to mention foreign lands. Television could be used to teach them simple ways and means to improve their own lot and their children's future in the circumstances in which they find themselves. I can visualize the application of television to convince the people of the need to control the population explosion, to improve their sanitary conditions, how to avoid malnutrition with available food. Without the use of this medium, I am afraid, the progress in developing countries will take too long, which would have a disastrous effect the world over. The cost of providing a network of television stations throughout these countries would be well worth the improvements in the lives of millions of people and would be repaid by the increase in production on the farms.

Organized research on an international scale, as you mention, of problems such as health, cheap housing, etc., can easily contribute towards the development of the developing countries. But what is foremost is the need for the realization by the leaders of these nations to orient, in the interest of the people they serve, their policies so as to attract capital from inside and outside the countries in order to enable them to exploit the technology which already exists or is developed by their own efforts for the solution of these problems. This would not only generate the growth of their economies but at the same time enable them gainfully to employ their trained manpower, since unemployment and under-employment of the vast number of the school leavers and graduates lead to serious social problems and no democracy can survive and grow with the existing social conditions of extreme poverty and misery.

$$
\text { Yours faithfully, }
$$

K. C. Tripathi

16 St John's Way,

Hempton,

Deddington,

Oxford $O X 54 Q R$

\section{Obituary Sir W. Le Gros Clark}

WheN Wilfrid Le Gros Clark went to Oxford in 1934 (after holding chairs at St Bartholomew's and St Thomas's Hospitals) to become Dr Lee's professor of anatomy at the age of 39, he was already the acknowledged master and leader in three exciting and expanding fields. Largely through the example of his own meticulous and imaginative investigations of the visual and olfactory pathways and of the connexions of the thalamus, descriptive neuroanatomy had begun to make way for much more significant enquiries into cerebral functional organization. The basis of $\mathrm{Le}$
Gros Clark's success in this field was laid by his researches into the comparative neurology of lower primates, particularly of tarsier and tree shrews, specimens of which he obtained during his time as principal medical officer in Sarawak (1920-23). This in turn led him deeply into primate and human evolution; his pre-eminence in this field was marked by the publication in 1934 of his influential Early Forerunners of Man, later revised in several editions as The Antecedents of Man (1959).

His creative and original approaches to neurology, morphology and phylogeny led him on to his reforming activities in both teaching and research in human anatomy and physical anthropology. In anatomy he insisted on experimentation to reveal the functional significance of structure as the way forward. His Tissues of the Body, now in its fifth edition, must have reconciled many a medical student to the load placed on him by an over-traditional subject. And he strove for the introduction of shorter textbooks, more in keeping with a modern curriculum, bringing out his own Practical Anatomy (1948) and later contributing to the Text Book of Human 


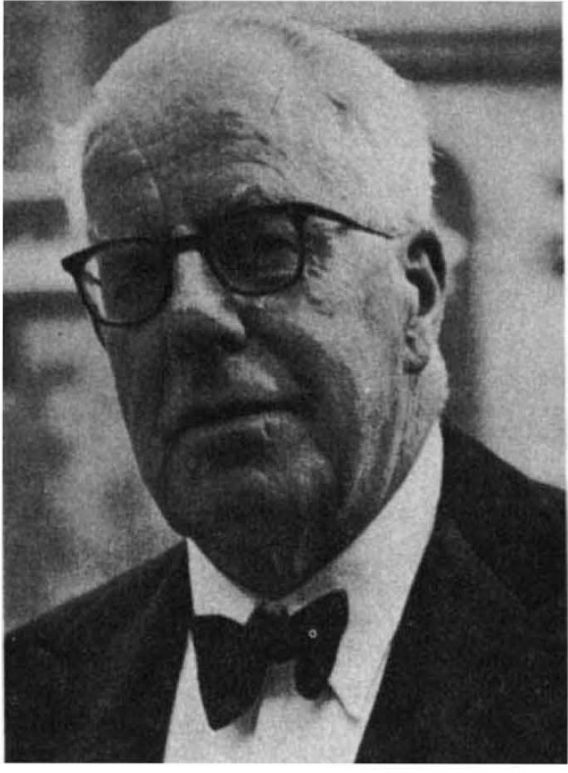

Anatomy (edited by W. J. Hamilton). Likewise, in physical anthropology, an old-established subject in Oxford, Le Gros Clark firmly opposed the traditional fare of craniometry and typology, advocating instead a genuine study of human variation in relation to both environmental and genetic factors.

All these issues were fostered by him in Oxford over the next 25 years. His vision and integrity, his positive outlook, his critical and creative power, his erudition, his unfailing kindliness, as well as the example of his own sustained productivity, made him an impressive and inspiring head of a large and many sided department. A stream of visitors and postgraduate students came to the department to work with, under, or just near 'Le Gros'.

In the war years a team under his lead demonstrated a new facet of functional anatomy by designing equipment to meet the visual, auditory, manipulative and postural requirements of Service personnel such as gunners performing complex tests of sighting and tracking.
This experience of "human engineering" or ergonomics convinced Le Gros Clark of its value for everyday activities, particularly in industry. An MRC unit, attached to his department and of which he was honorary director (19481962), pursued a programme devoted largely to practical applications of functional anatomy, human physiology and physical anthropology.

In the last decade of his tenure at Oxford, Le Gros Clark continued his neurological work but became more and more immersed in his palaeontological interests. On a visit to South Africa he was able to study at first hand the australopithecine material, accumulated by Raymond Dart and Robert Broom. $\mathrm{He}$ became entirely convinced of the hominid status of these creatures, though he remained sceptical of the proved existence of a form as advanced as Homo habilis. He also carried out the definitive descriptions of the pre-hominid material (notably Proconsul) discovered by Louis Leakey. In all this he was never a mere taxonomist, but strove always to define the phylogenetic processes at work. His conclusions on the course of primate and human evolution are set out succinctly in three notable books, History of the Primates (8th edition, 1967), The Fossil Evidence for Human Evolution (1955), and Man Apes or Ape Men? (1967). Le Gros Clark also contributed significantly to the solution of the long standing Piltdown problem (1953).

Somewhat to his surprise Le Gros Clark encountered not inconsiderable opposition both to his reforming activities and to his views on fossil man. Polemics he found distasteful and distressing, but he was a formidable protagonist in controversy, deriving his strength from the painstaking and concentrated consideration and reconsideration he gave to everything he studied.

In some ways Le Gros Clark was a man of paradox. While he went to considerable trouble to discourage the study of anatomical minutiae, he himself retained an awesome knowledge of the detailed macro and micro-anatomy of the human frame and indeed delighted in the art of topographical disquisition. He heartily disliked administration, the role of "organization man" or "scientistpolitician" was not to his taste; yet he directed his large department unobtrusively and with efficiency, paying careful attention to its rebuilding, expansion and modernization. He remained a firm believer in simple apparatus and simple experimentation, and often expressed scepticism of the need for expensive equipment, even of the electron microscope; nevertheless when fully convinced, he would spare no trouble to see that the necessary equipment was obtained. For a generation Le Gros Clark was the outstanding British anatomist and its leader, yet he strove always to keep aloof from scientific politics, though in a few crises when he felt impelled to intervene his influence was decisive.

Le Gros Clark was elected to the Royal Society in 1935 and awarded a Royal Medal in 1961. He was president of the International Anatomical Congress at Oxford in 1950, president of the Anatomical Society in 1952 and 1953 and president of the British Association in 1961. He also served on the Medical Research Council. He was a member and master (1954) of the Salters Company and fellow of Hertford College, Oxford. He was knighted in 1955 and retired in 1962. He published a volume of memoirs, Chant of Pleasant Exploration, in 1968.

In 1923 he married Freda Constance Giddey, by whom he had two daughters. Freda Le Gros Clark died in 1963. In 1964 he married Violet, widow of $\mathrm{Dr}$ Leonard Browne.

The combination of Wilfrid Le Gros Clark's gifts and the diversity of his interests has without doubt made a long-lasting impression on the content and style of British anatomy and allied disciplines.

\section{HOW TO BUY NATURE}

Volumes start in January, March, May, July, September and November, but subscriptions may begin at any time.

The direct postal price per subscription is:

12 MONTHS * (52 issues per title)

\begin{tabular}{|c|c|c|c|}
\hline & \multirow{2}{*}{$\begin{array}{l}\text { Surface Mail } \\
\text { UK and } \\
\text { worldwide }\end{array}$} & \multicolumn{2}{|c|}{ Airfreight } \\
\hline & & U.S.A. & Canada \\
\hline Nature (Friday) & $\varepsilon 14$ & $\$ 48$ & $\$ 52$ \\
\hline $\begin{array}{l}\text { Nature }+ \\
\text { Nature Physical Science }\end{array}$ & E24 & $\$ 83$ & $\$ 90$ \\
\hline $\begin{array}{l}\text { Nature }+ \\
\text { Nature New Biology }\end{array}$ & $£ 24$ & $\$ 83$ & $\$ 90$ \\
\hline All three editions & $£ 29.50$ & $\$ 108$ & $\$ 116$ \\
\hline Annual Index & f1 & \$3 & $\$ 3$ \\
\hline
\end{tabular}

* Rates for shorter periods pro rata (minimum three months) (Charge for delivery by air mail on application)
Editorial and Publishing Offices of NATURE

MACMILLAN JOURNALS LIMITED

4 LITTLE ESSEX STREET, LONDON WC2R 3LF

Telephone Number : $01-8366633$. Telegrams : Phusis London WC2R 3LF

711 NATIONAL PRESS BUILDING

WASHINGTON DC 20004

Telephone Number : 202-7372355

Subscription Department

MACMILLAN JOURNALS LIMITED

BRUNEL ROAD, BASINGSTOKE, HANTS

Telephone Number : Basingstoke 5431

American display advertisements

NATURE SCIENTIFIC PUBLICATIONS INC

711 NATIONAL PRESS BUILDING WASHINGTON DC 20004

Al/ other advertisements

T. G. SCOTT \& SON, LIMITED

1 CLEMENT'S INN, LONDON WC2A 2ED

Telephone : 01-242 6264/01-405 4743

Telegrams : Textualist London WC2A 2ED

Registered as a newspaper at the Post Office

Copyright (C) Macmillan Journals Limited, August 61971 